\title{
Clearing mechanisms of Vibrio vulnificus biotype I in the black tiger shrimp Penaeus monodon
}

\author{
V. Alday-Sanz ${ }^{1}$, A. Roque ${ }^{2}$, J. F. Turnbull ${ }^{3, *}$ \\ ${ }^{1}$ Diagnostic Unit, Center for Aquaculture Services, PO BOX 09-01-4519, Guayaquil, Ecuador \\ ${ }^{2}$ Centro de Investigacion en Alimentacion y Desarrollo, Sabalo Cerritos S/N, Estero del Yugo, CP 82010 AP711, Mazatlan, \\ Sinaloa, Mexico \\ ${ }^{3}$ Institute of Aquaculture, University of Stirling, Stirling, FK9 4LA, Scotland, UK
}

\begin{abstract}
Vibrio species' infections are a common sequelae to environmental stress or other disease processes in shrimp, but the mechanism by which the shrimp eliminate the bacteria is poorly understood. In this study, the penetration, fate and the clearing of $V$. vulnificus were investigated in Penaeus monodon. A bacterial disease isolate from a shrimp farm was identified as $V$. vulnificus biotype I. Polyclonal antiserum was raised in rabbits against the bacterium and the specificity was verified by ELISA and immunoblot against a range of Vibrio spp. and other Gram-negative bacteria. The bacteria were then administered to $P$. monodon juveniles by injection, immersion and oral intubation. An indirect immunoperoxidase technique was employed in a time course study to follow the bacteria and bacterial antigens in the tissue of the shrimp. Bacteria were cleared by a common route, regardless of the method of administration. Observations in immersion challenge were similar to a combination of those for oral and injection challenges. With immersion, bacteria entered the shrimp through damaged cuticle or via insertion points of cuticular setae. Shortly after entry, whole bacterial cells were observed in the haemolymph and connective tissue. They were either phagocytosed by haemocytes, or broken down outside host cells. Haemocytes containing bacterial cells or antigens (HCB) were observed in the connective tissue and haemolymph. HCB accumulated around the hepatopancreas, midgut, midgut-caecum, gills, heart and lymphoid organ. Free bacterial antigens also accumulated in the heart and lymphoid organ. Bacteria entering through the mouth by oral intubation or immersion were broken down so that only soluble or very fine particles entered the hepatopancreas. Bacterial antigens passed through the hepatopancreas into the haemolymph. Antigens were initially observed in the haemolymph sinuses and subsequently accumulated in the heart and lymphoid organ. Bacterial antigens were released from the shrimp, initially through the gills and subsequently through hepatopancreatic B-cells, branchial podocytes and sub-cuticular podocytes.
\end{abstract}

KEY WORDS: Shrimp $\cdot$ Vibrio $\cdot$ Penaeus monodon

\section{INTRODUCTION}

Infection of shrimp with Vibrio species (vibriosis) is a common sequelae to injury, stress or disease associated with other pathogens (Sparks 1981, Brock \& Lightner 1990). However, experimental reproduction is still problematic (Roque et al. 1998) and the mechanisms used by the shrimp to eliminate bacteria are not yet

${ }^{*}$ Corresponding author. E-mail: jftl@stir.ac.uk clearly understood. It is important to understand the interaction between host and bacteria in order to develop more effective methods of prevention and control.

The objective of this study was to develop a better understanding of the route of bacterial entry, the fate of the bacteria within the shrimp and the mechanisms of clearing. In these experiments, shrimp were challenged by a variety of routes, and bacterial antigens were subsequently detected using an immunoperoxidase technique. 


\section{MATERIALS AND METHODS}

Vibrio vulnificus. The isolate of Vibrio sp. used in this study was obtained from a disease outbreak in a shrimp farm in Thailand. The biochemical and structural characteristics of the isolates identified it as a $V$. vulnificus biotype I (VvbI) (Baumann et al. 1984). A standard curve of colony forming units (cfu) versus optical density (OD) was prepared in order to estimate the concentration of $\mathrm{cfu}$ used in the different challenges. Bacteria were grown in Tryptone Soya Broth $(2 \% \mathrm{NaCl})$ at $22^{\circ} \mathrm{C}$ for $24 \mathrm{~h}$; the broth was centrifuged (2200 $\mathrm{g}$ at $4^{\circ} \mathrm{C}$ for $20 \mathrm{~min}$ ) and the pellet washed twice and re-suspended in sterile saline. This suspension was diluted to the following ODs read at $610 \mathrm{~nm}$ in a spectrophotometer: 1.0, 0.8, 0.6, 0.5, 0.3, and 0.2. Each of these suspensions $(0.1 \mathrm{ml})$ was plated on Tryptone Soya Agar $(2 \% \mathrm{NaCl})$ in triplicate and incubated at $22^{\circ} \mathrm{C}$ for $24 \mathrm{~h}$. The number of colonies was counted and an average $\mathrm{cfu} \mathrm{\textrm {ml } ^ { - 1 }}$ calculated and plotted against the $O D$ at $610 \mathrm{~nm}$ (data not shown). With a suspension of $5 \times 10^{6} \mathrm{cfu} \mathrm{m}^{-1}$, the lethal dose that kills $50 \%$ of exposed individuals $\left(\mathrm{LD}_{50}\right)$ of the isolate was approximately $3 \%$ of the shrimp body weight after blotting (Roque 1995).

An antiserum against the strain (anti-VvbI) was raised in rabbits using $1 \times 10^{8} \mathrm{cfu}$ shrimp $^{-1}$ of killed bacteria $\left(60^{\circ} \mathrm{C}\right.$ for $\left.1 \mathrm{~h}\right)$. Three consecutive subcutaneous inoculations were performed at $3 \mathrm{wk}$ intervals and a final intravenous boost was administered after a further $10 \mathrm{~d}$. Blood was collected $7 \mathrm{~d}$ later and the serum separated. The specificity of the serum was determined by ELISA, immunoblot (Adams 1998) against Vibrio spp. and other bacteria. Serum collected prior to immunisation was used as the negative control. A Western blot (Adams 1998) was employed to identify the components of the bacteria with which the antiserum reacted. For the purpose, outer membrane proteins and lipopolysaccharide (LPS) were extracted (Filip 1973) and used in the Western blot. The antiserum was later used in an indirect peroxidase-labelled antibody method (Alday-Sanz et al. 1994) to detect bacterial antigens in shrimp tissues after challenge. Briefly after de-waxing and blocking, endogenous peroxidase activity with $\mathrm{H}_{2} \mathrm{O}_{2}$ sections were incubated with rabbit anti-VvbI diluted 1:800 in Tris-buffered saline (TBS). They were then incubated with donkey anti rabbit antiserum conjugated with horseradish peroxidase diluted 1:50 in TBS, and incubated for $10 \mathrm{~min}$ with 3, 3 diamino benzidine tetrahydrochloride (DAB). Normal donkey serum was used as a control. Consequtive serial sections were stained with haemotoxylin and eosin (H\&E) for comparison.

Shrimp. Except for the oral challenge, the Penaeus monodon used were between 0.8 and $1 \mathrm{~g}$ in weight and 2.5 to $3 \mathrm{~cm}$ in length (base of rostrum to the base of telson). The oral challenge required larger shrimp of approximately $11 \mathrm{~g}$ in weight and $10 \mathrm{~cm}$ in length. Eight static water aquaria each with a capacity of 201 were used, the temperature was maintained at $29 \pm$ $1^{\circ} \mathrm{C}$ and the salinity at $27 \mathrm{ppt}$. Shrimp were fed ad libitum on fresh mussels once every $24 \mathrm{~h}$.

Shrimp used for the oral intubation and immersion challenges were subjected to a period of stress prior to bacterial exposure in an attempt to reproduce the circumstances under which vibriosis occurs naturally. Exposure to high levels of ammonia in the tank water was selected as the stressor (see below). Control animals and those used for injection challenges were not exposed to ammonia. A summary of the challenges and the sampling procedures is shown in Table 1.

Oral intubation. A total of 37 shrimp were challenged in 2 experiments, $48 \mathrm{~h}$ after exposure to $20 \mathrm{mg}$ $\mathrm{l}^{-1}$ of total ammonia ( $\mathrm{pH} 7.9$ to 8.2 ), by introducing $1 \times 10^{8} \mathrm{cfu}$ shrimp ${ }^{-1}$ directly into the stomach. A bluntended needle attached to an insulin syringe was gently inserted through the mouthparts before inoculation of the bacterial suspension. Other shrimp were exposed to bacteria but not to the ammonia. Two shrimp from the bacteria and ammonia treatment and 2 from the bacteria alone treatment were sampled for immunohistochemistry and histology on each of 8 occasions from $30 \mathrm{~min}$ to $72 \mathrm{~h}$ post-inoculation.

Immersion challenges. Shrimp were either exposed to bacteria alone or bacteria and ammonia. A total of 242 shrimp were used in 6 experiments. For approximately $60 \%$ of the shrimp $20 \mathrm{mg} \mathrm{l}^{-1}$ of total ammonia (pH 7.9 to 8.2) was added to the tanks. Forty-eight hours later sufficient bacteria were added to all the experimental tanks to produce a concentration of $5 \times$ $10^{5} \mathrm{cfu} \mathrm{ml^{-1 }}$. During the series of experiments $2 \mathrm{shrimp}$ from each treatment were sampled for immunohisto-

Table 1. Summary of the challenges and sampling procedure

\begin{tabular}{|lccccc|}
\hline Challenge & No. of experiments & Total no. of ind. & Application of stress & Sampling interval & No. of samples \\
\hline Oral intubation & 2 & 37 & + & $30 \mathrm{~min}-72 \mathrm{~h}$ & 8 \\
Immersion & 6 & 224 & + & $10 \mathrm{~min}-15 \mathrm{~d}$ & 65 \\
Injection of whole bacterial cells & 3 & 20 & - & $10 \mathrm{~min}-96 \mathrm{~h}$ & 16 \\
Injection of sonicated material & 1 & & - & $10 \mathrm{~min}-24 \mathrm{~h}$ & 12 \\
\hline
\end{tabular}


chemistry and histology on each of 65 occasions from $10 \mathrm{~min}$ to $15 \mathrm{~d}$ after introduction of the bacteria. Control shrimp were taken from untreated tanks.

Injection challenges. Two different injection challenges were performed, one with live bacterial cells and one with sonicated cells. In 3 experiments, live cells were injected into $48 \mathrm{shrimp}$ at $5 \times 10^{5} \mathrm{cfu}_{\text {shrimp }}{ }^{-1}$ in $0.05 \mathrm{ml}$ between the $3 \mathrm{rd}$ and 4 th abdominal segment. Control animals were injected with sterile saline. Two experimental and 2 control shrimp were sampled on each of 12 occasions from $10 \mathrm{~min}$ to $96 \mathrm{~h}$ after injection.

In another experiment, 20 shrimp were injected with $0.05 \mathrm{ml}\left(0.9 \mathrm{mg}\right.$ protein $\left.\mathrm{ml}^{-1}\right)$ in a sonicated suspension of $1 \times 10^{7} \mathrm{cfu} \mathrm{ml}^{-1}$ between the $3 \mathrm{rd}$ and 4 th abdominal segment. Again controls were injected with sterile saline. Two shrimp were sampled on each of 10 occasions, from $10 \mathrm{~min}$ to $24 \mathrm{~h}$ post-injection. This procedure was performed in order to study the fate of bacterial material in the absence of active colonisation.

A Vibrio anguillarum injection challenge was also carried out in order to confirm the in vivo specificity of the antiserum used for immunoperoxidase. A total of 8 shrimp were injected between the 3rd and 4th abdominal segments with $5 \times 10^{5} \mathrm{cfu}$ of $V$. anguillarum shrimp $^{-1}$ as estimated by the VvbI standard curve in $0.05 \mathrm{ml}$.

At the time of sampling, shrimp were fixed with Davidson's fixative and processed for histological examination, following standard procedures (Bell \& Lightner 1988). Sections were prepared for H\&E staining and for immunoperoxidase study.

Effect of shrimp hepatopancreatic extracts on bacterial cells. Bacteria were incubated with a range of concentrations of hepatopancreatic extracts and stomach contents. These 2 organs were removed from 5 shrimp under sterile conditions, ground and mixed with a volume of saline water twice the weight of the tissue. The mixture was centrifuged at $1800 \mathrm{~g}$ for $10 \mathrm{~min}$ and the supernatant fluid was filtered through a $0.22 \mu \mathrm{m}$ membrane. Next, $100 \mu \mathrm{l}$ of $108 \mathrm{cfu} \mathrm{ml}^{-1}$ of VvbI was incubated with $100 \mu \mathrm{l}$ of the extract or its dilutions $(1: 10$, $1: 100,1: 1000)$ in wells of a microtitre plate. For controls, bacteria at equal dilutions were incubated with sterile saline. The plates were incubated at $30^{\circ} \mathrm{C}$ and $20 \mu \mathrm{l}$ from each well was collected after $10 \mathrm{~min}, 30 \mathrm{~min}$, $1 \mathrm{~h}$ and $2 \mathrm{~h}$ and spread on TSA for colony counting.

\section{RESULTS}

The results from the immunoblot are summarised in Table 2 and from the ELISA in Table 3. The absorbance value for VvbI using pre-immunised serum at 1:800 dilution was 0.167 at $450 \mathrm{~nm}$. A dilution of 1:800 was also used for the indirect immunoperoxidase reac-
Table 2. Results from the immunoblot assay using antiVibrio vulnificus biotype I isolate serum. +: positive reaction; -: negative reaction

\begin{tabular}{|lcccccccc|}
\hline \multirow{2}{*}{ Organism } & \multicolumn{7}{c|}{ Dilution } \\
& $1: 1$ & $1: 2$ & $1: 10$ & $1: 20$ & $1: 50$ & $1: 100$ \\
\hline Vibrio vulnificus BT I & + & + & + & + & + & + \\
V. fluvialis & + & + & + & + & - & - \\
V. anguillarum & + & + & + & + & - & - \\
V. alginolyticus & + & + & + & - & - & - \\
Plesiomonas shigelloides & + & + & - & - & - & - \\
V. parahaemolyticus & + & + & + & + & - & - \\
V. vunificus & + & + & + & + & - & - \\
Escherichia coli & + & + & - & - & - & - \\
Pseudomonas fluorescens & + & + & - & - & - & - \\
\hline
\end{tabular}

tions. The results of the Western blot identified 2 molecules from the outer membrane of the VvbI isolate as antigens, a $31 \mathrm{kDa}$ protein and a 90 to $99 \mathrm{kDa}$ fraction with an appearance suggestive of LPS. Bacteria administered orally entered the shrimp only via the gut. They were disrupted in the stomach into 2 components (Fig. 1). The first comprised coarser material which was observed in the intestine within $30 \mathrm{~min}$ and was fully eliminated via the faeces within $9 \mathrm{~h}$. The second component, containing fine material apparently in solution, passed into the lumen of the hepatopancreas through the gastric sieve. Free bacterial components (FBC) resulting from bacterial cell disruption were observed throughout the hepatopancreatic tubules within $1 \mathrm{~h}$ (Fig. 2), after which they moved into the hepatopancreatic haemolymph sinuses (Fig. 3). From there they moved into the general circulation. No intact bacteria were observed in the hepatopancreas, nor the mid-gut. The only difference between ammoniastressed and control shrimp was that the stressed shrimp cleared the absorbed bacterial material more slowly. The control shrimp cleared the material on average after $24 \mathrm{~h}$ and those exposed to ammonia after, on average by $36 \mathrm{~h}$.

Table 3. Absorbance values from ELISA with a range of organisms at 1:800 dilution using anti-Vibrio vulnificus biotype I serum

\begin{tabular}{|lc|}
\hline Organism & Absorbance \\
\hline Vibrio vulnificus BT I & 1.449 \\
V. fluvialis & 0.691 \\
V. anguillarum & 0.737 \\
V. alginolyticus & 0.453 \\
Plesiomonas shigelloides & 0.360 \\
V. parahaemolyticus & 0.517 \\
V. vunificus & 0.117 \\
Escherichia coli & 0.351 \\
Pseudomonas fluorescens & 0.075 \\
\hline
\end{tabular}



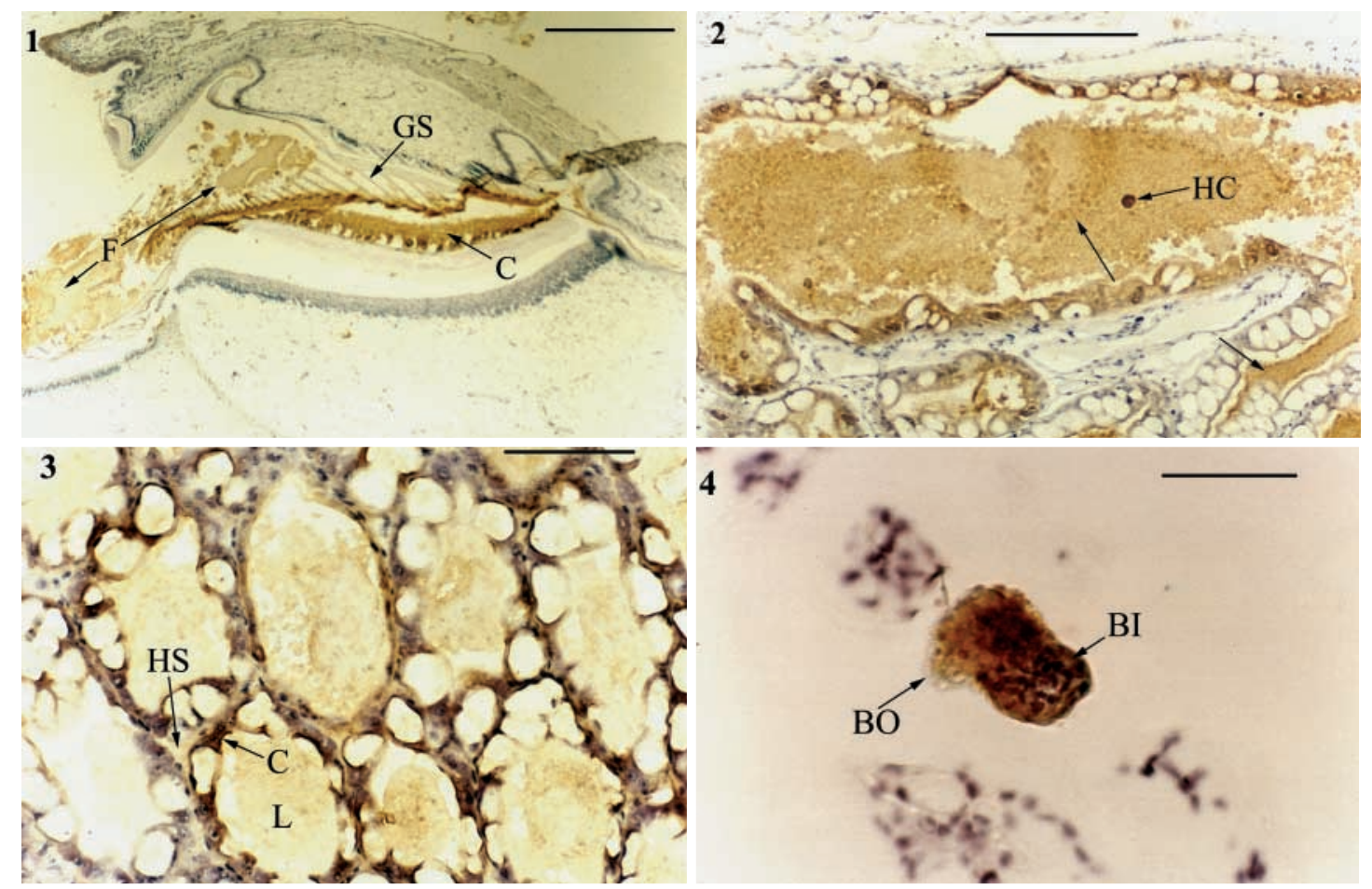

5
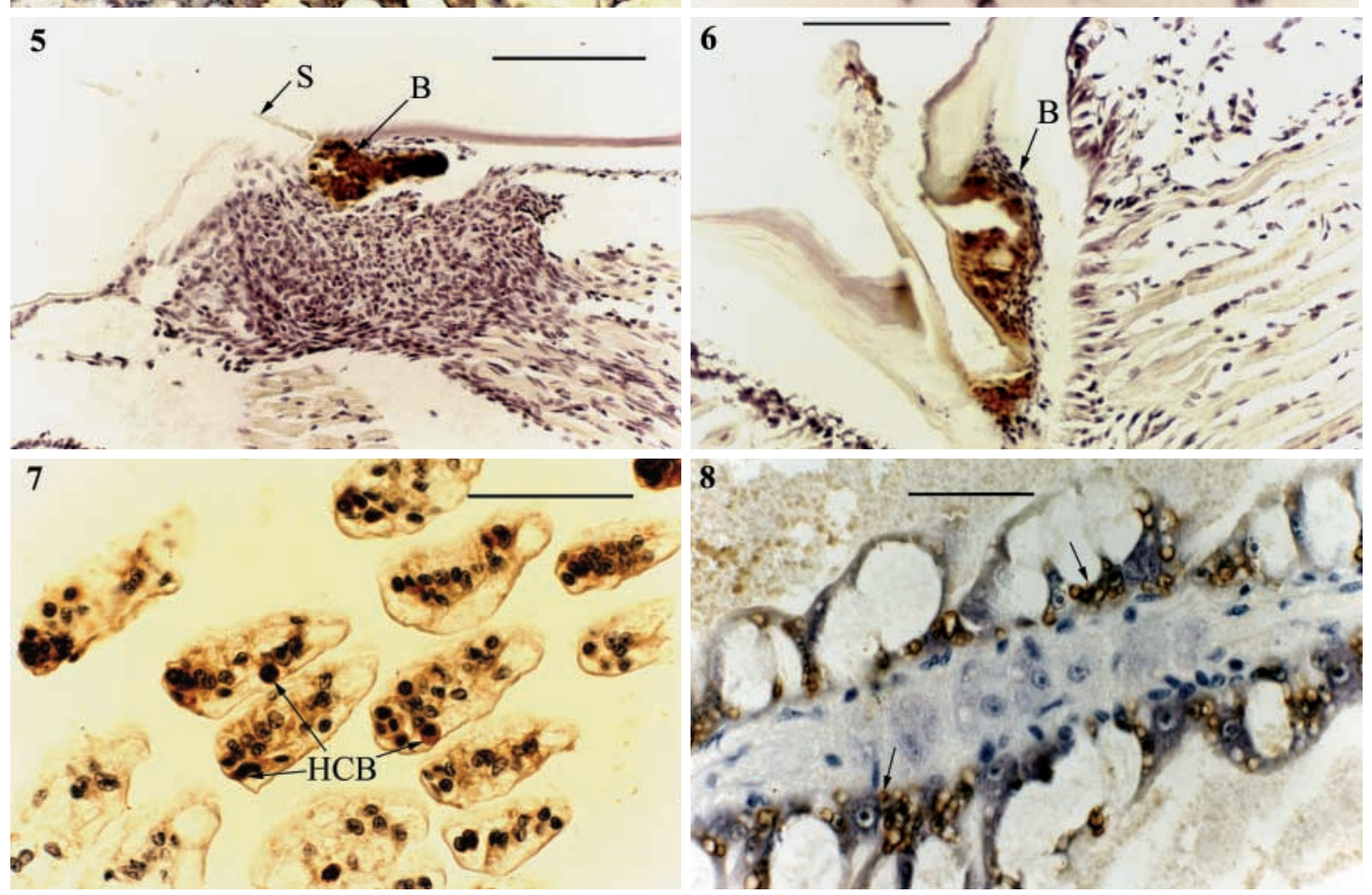

Figs. 1 to 8. Vibrio vulnificus infecting Penaeus monodon. Fig. 1. The bacterial antigens were separated in the stomach into coarser material $(\mathrm{C})$ that was observed within the intestine and fine material $(\mathrm{F})$, apparently in solution, which passed through the gastric sieve (GS) into the lumen of the hepatopancreas. (30 min after oral administration, Immunoperoxidase, scale bar $=100 \mu \mathrm{m}$.) Fig. 2. Positively stained material $(\rightarrow$ ) was observed throughout the hepatopancreatic tubules. There was also a positively stained sloughed hepatopancreatic cell (HC) within one of the tubules. (30 min after oral administration, Immunoperoxidase, scale bar $=50 \mu \mathrm{m}$.) Fig. 3. Positively stained material was observed in the lumen (L) and cells $(\mathrm{C})$ of the hepatopancreatic tubules and the haemolymph sinuses (HS). (1 h after oral administration, Immunoperoxidase, scale bar $=20 \mu \mathrm{m}$.) Fig. 4. Bacteria were observed on the outside (BO) and inside (BI) the gills. (10 min after immersion administration, Immunoperoxidase, scale bar $=10 \mu m$.) Fig. 5. Bacteria and an associated haemocytic response (B) were observed at the insertion of setae (S). (20 min after immersion administration, Immunoperoxidase, scale bar $=50 \mu \mathrm{m}$.) Fig. 6. Bacteria and an associated haemocytic response (B) were observed around areas of apparently damaged cuticle. (80 min after immersion administration, Immunoperoxidase, scale bar $=50 \mu \mathrm{m}$.) Fig. 7. Haemocytes containing bacterial components (HCB) were observed in the haemolymph sinuses of the gills. $(1 \mathrm{~h}$ after injection administration, Immunoperoxidase, scale bar $=5 \mu \mathrm{m}$.) Fig. 8. Positively stained material $(\rightarrow)$ was observed in the R-cells of the hepatopancreas. $(6 \mathrm{~h}$ after immersion administration, Immunoperoxidase, scale bar $=10 \mu \mathrm{m}$ ) 
By immersion challenge, bacteria penetrated through gills (Fig. 4), insertions of the setae (Fig. 5) and possibly damaged cuticle (Fig. 6). Some bacteria formed small superficial colonies on areas of undamaged thick cuticle. These colonies did not appear to penetrate the cuticle. Bacteria that entered the mouth followed the fate described previously for the oral challenge. Bacteria that entered shrimp tissues through the surface were associated with a haemocytic response less than 20 min after immersion. These bacteria were either disrupted in situ (after which they were indistinguishable from FBC from other sources) or they were phagocytosed. FBC itself did not elicit any visible cellular haemocytic response. The haemocytes containing bacteria and bacterial compounds (HCB) were seen in the haemolymph and in connective tissue (Fig. 7). Six hours after immersion positively stained material was observed in the vacuoles of the R-cells in the hepatopancreas (Fig. 8). Bacteria injected into muscle caused a reaction similar to bacteria entering through the cuticle but over a larger area. They were either phagocytosed or disrupted outside cells with a fate similar to that seen for bacteria in the immersion challenge.

After 2 to $4 \mathrm{~h} \mathrm{FBC}$ and HCB present in haemolymph and connective tissue accumulated in the gills (Fig. 9) and around the hepatopancreas (Fig. 10) midgut caeca and antennal gland. FBC also accumulated in the heart and lymphoid organ. In the heart FBC appeared to be attached to the outside of muscle bundles and did not enter cells. In the lymphoid organ FBC were observed within the normal tubule stromal matrix but to a lesser extent within spheroids (Fig. 11). By 8 to $9 \mathrm{~h}$ after challenge only small quantities of FBC were present in the heart and lymphoid organ. During this time, however, the amount of FBC in the gills increased. In several areas, FBC accumulated on the surface of gill epithelial cells in small areas under the cuticle.

In addition to the material apparently excreted through the gills, FBC were also retained within branchial podocytes and subcuticular cells with a similar appearance to podocytes (Fig. 12). Podocytes containing FBC were observed after 2 to $3 \mathrm{~d}$ and their numbers increased up to the end of the experiments (15 d after challenge). After $8 \mathrm{~d}, \mathrm{FBC}$ also accumulated in the B-cell vacuoles (Fig. 13). In some cases these vacuoles appeared to discharge into hepatopancreatic tubules and then the gut.

The shrimp which were exposed to ammonia prior to the immersion challenge, showed more frequent and earlier pathological changes than shrimp exposed to bacteria alone. However, there were insufficient differences between these groups to confirm such trends conclusively. Control shrimp injected with sterile saline showed a lower number of haemocytes than those injected with whole or sonicated bacteria.
The fate of the sonicated material injected into the shrimp was similar to that of the FBC described previously for oral, immersion and injection challenge. The shrimp injected with Vibrio anguillarum showed similar histopathological changes to those injected with VvbI; however, there was no positive reaction (Fig. 14). Negative controls also confirmed the specificity of the reaction. Immunoperoxidase sections compared with those stained with H\&E not only ensured that there was no confusion with the melanin deposits but also demonstrated the presence of bacterial antigens that would not have been visible in H\&E sections alone (Fig. 15). The results relating to the fate of the bacteria and the bacterial antigens are summarised in Fig. 16.

The hepatopancreatic extracts, did not have any significant effect on bacterial survival at any concentration.

\section{DISCUSSION}

This study utilised a polyclonal antiserum that reacted with specific components of VvbI and an immunoperoxidase method was used to localise those antigens. Specificity was confirmed not only by the immunoblot and ELISA but also by immunohistochemical results that were positive with VvbI and negative with Vibrio anguillarum following injection. However, the possibility of cross-reaction with shrimp epitopes was not examined. The distribution of reaction over the time course study and in the shrimp injected with $V$. anguillarum would suggest that there was no reaction with widespread or fixed epitopes, but the possibility of cross-reaction with some aspect of the mobile defence mechanisms cannot be ruled out on current evidence. Application of controls and examination of serial sections stained with H\&E suggested the presence of bacterial antigens associated with whole bacterial cells, HCB and FBC. H\&E sections were used to differentiate between a positive immunoperoxidase reaction and endogenous melanin.

Using this immunoperoxidase method, results from bacterial challenge showed that the fate of the bacteria converged on common pathways regardless of the route of administration. All these pathways were evident in bath challenges where the first signs of a positive test reaction were observed on the surface of gill lamellae where bacterial cells accumulated. This suggested the gills were a possible route for bacterial entry, as already proposed by Lavilla-Pitogo et al. (1990) and Smith \& Ratcliffe (1976). Thus, gill health might be expected to have a significant effect on the potential for bacterial infection.

Bacteria were also found superficially attached to other uninterupted cuticular areas (i.e. without setae) 

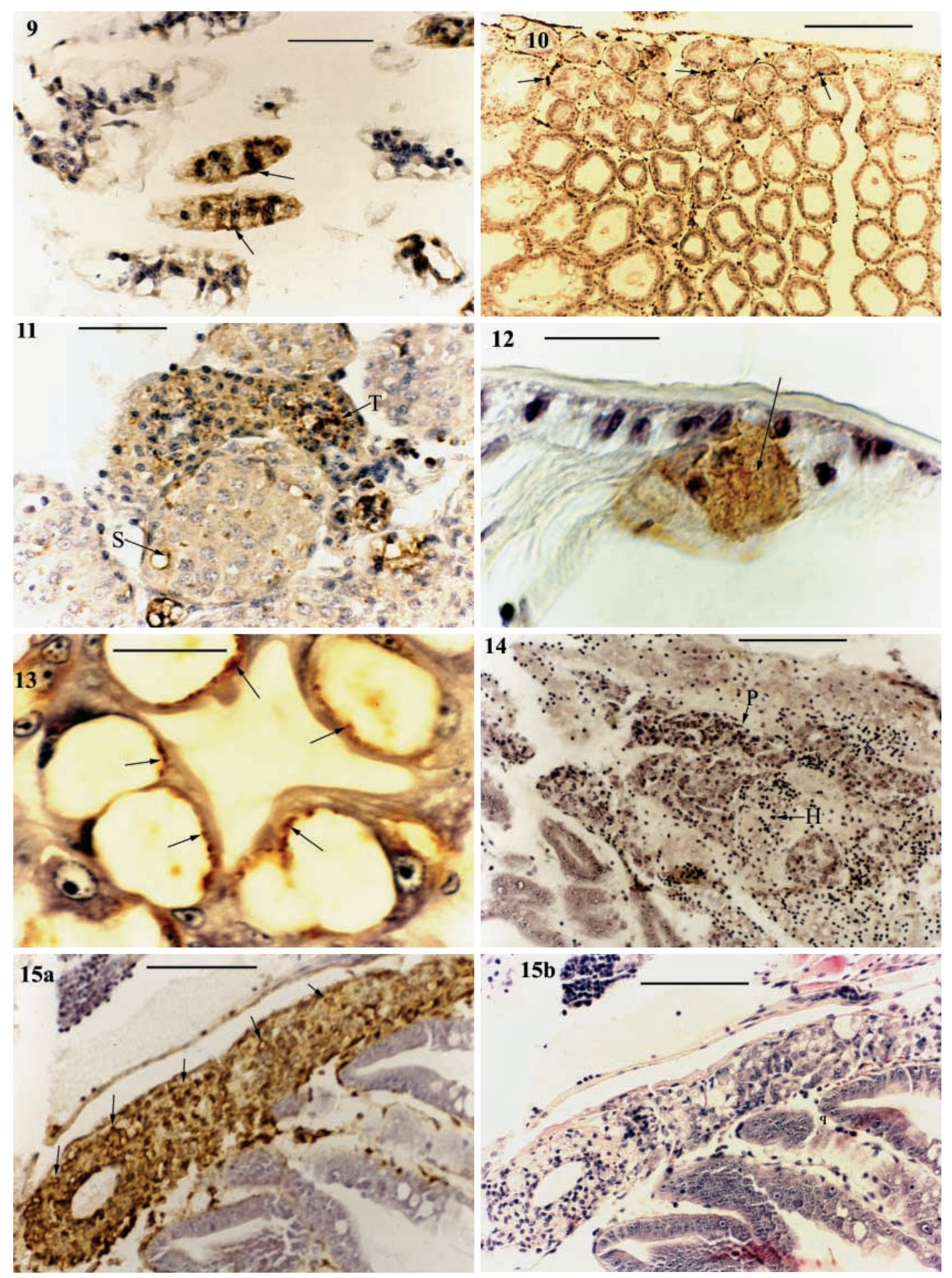

Figs. 9 to 15. Vibrio vulnificus infecting Penaeus monodon. Fig. 9. Positively stained material $(\rightarrow)$ was observed in the gills. $(4 \mathrm{~h}$ after injection administration, Immunoperoxidase, scale bar $=10 \mu \mathrm{m}$.) Fig. 10. Positively stained material $(\rightarrow)$ both free and contained within cells was observed in the hepatopancreas. ( $2 \mathrm{~h}$ after injection administration, Immunoperoxidase, scale bar $=50 \mu \mathrm{m}$.) Fig. 11. Positively stained material was observed in the lymphoid organ mostly within the tubular walls (T) but also to a lesser ex-

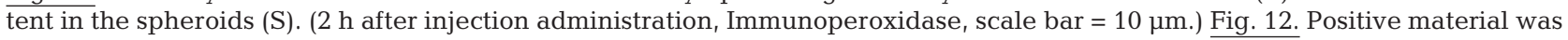
also observed in subcuticular cells. (4 d after immersion administration, Immunoperoxidase, scale bar $=5 \mu \mathrm{m}$.) Fig. 13 . Positively stained material was observed in the B-cell vacuoles of the hepatopancreas $(\rightarrow)$. (8 d after immersion administration, Immunoperoxidase, scale bar $=5 \mu \mathrm{m}$.) Fig. 14. In this shrimp injected with $V$. anguillarum accumulations of haemocytes (H) and pyknotic nuclei (P) were observed in the lymphoid organ but there was no positive immunoperoxidase reaction. (4 h after injection administration, Immunoperoxidase, scale bar $=50 \mu \mathrm{m}$.) Fig. 15. Serial sections from a shrimp stained with immunoperoxidase and H\&E. (a) Staining of bacterial components clearly visible $(\rightarrow)$. (4 $\mathrm{h}$ after injection administration, Immunoperoxidase, scale bar $=50 \mu \mathrm{m})$

(b) No evidence of bacterial components. ( $4 \mathrm{~h}$ after injection administration, H\&E, scale bar $=50 \mu \mathrm{m}$ ) 


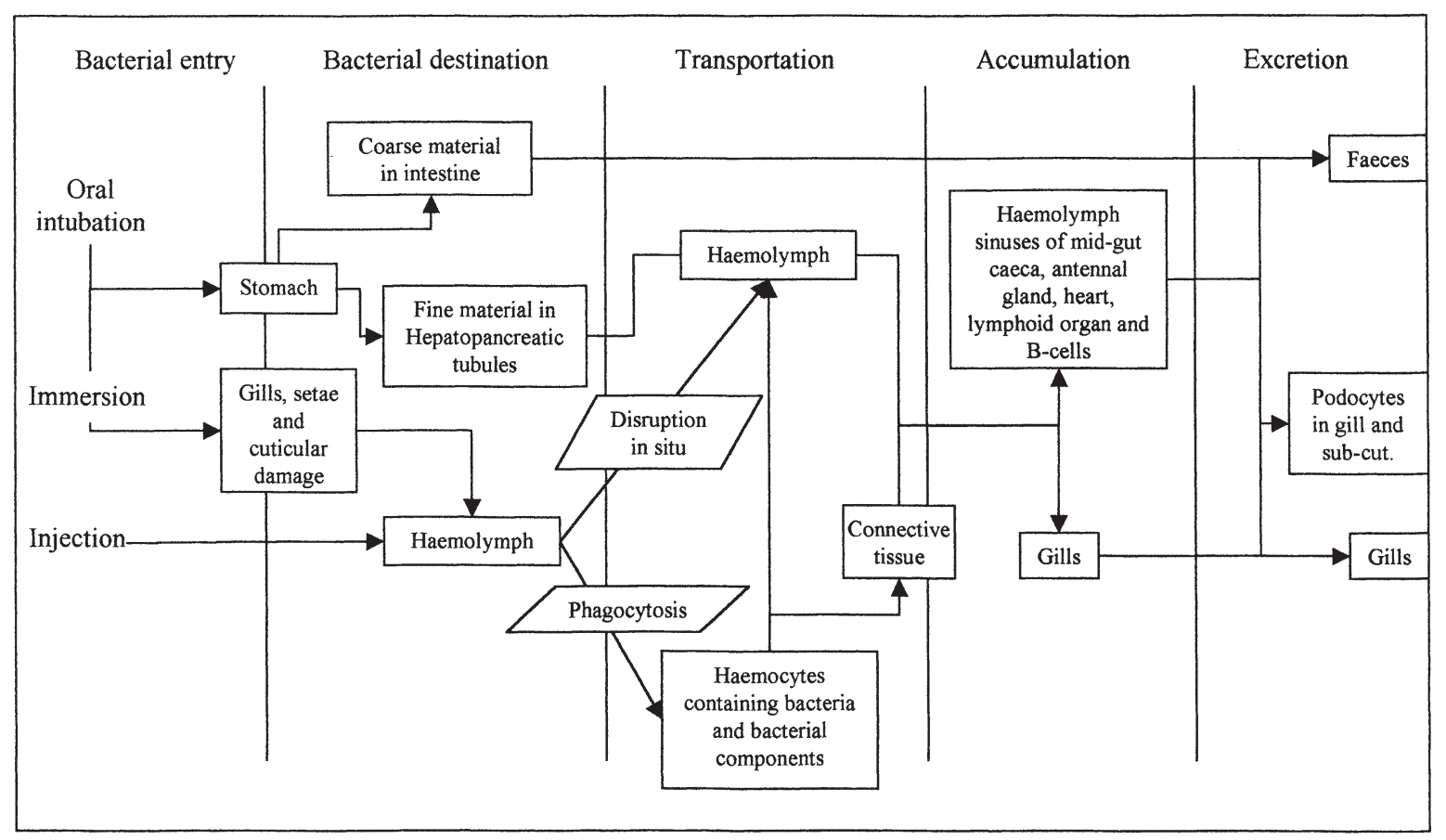

Fig. 16. Diagrammatic representation of proposed fate of Vibrio vulnificus biotype I administered to Penaeus monodon by 3 routes

but did not seem to be able to penetrate the shrimp, although it is possible that the intact cuticle could be penetrated under other circumstances or by other strains or species of Vibrio. However, penetration was observed in areas where there were cuticular setae and this provoked a large haemocytic response. In these areas the cuticle tended to be relatively thin, similar to the gills, when compared with the general, smooth exoskeleton, and this bacterial penetration might be related to pre-existing damage. By contrast, there was a notable absence of immunoperoxidase reaction in the tegmental glands, which have ducts to the cuticular surface.

The response to invading bacteria was rapid. Haemocytes migrated to damaged subcuticular areas to phagocytosed invading bacteria. The resulting HCB appeared to migrate through the subcuticular connective tissue since they could be found some distance away from invasion sites. This finding supported Mellon's (1992) description of crustacean connective tissue as playing a role in the migration of elements of the circulatory and immune system.

Bacteria that entered the digestive tract through the mouth during immersion or intubation, were disrupted in the stomach so that only soluble material and fine particles could be observed in hepatopancreatic tubules. This positively reacting material moved to the haemolymph, where it did not provoke any visible host response such as haemocytic aggregation, although it may have pro- duced humoral response. For example, LPS present in Gram-negative bacterial cell walls is known to trigger elements of the of the prophenyl oxidase (proPO) defence system in crustaceans (Soderhall 1998). Indeed, microbial LPS and glucan preparations are sold commercially as food additives for immunoenhancement in shrimp and fish aquaculture. Even though these additives have been shown to stimulate defence reactions such as phagocytosis in vitro (Soderhall 1998), this is the first report indicating that bacterial cell wall components can enter shrimp haemolymph via the oral route.

The cells observed in the cuticular connective tissue with an appearance similar podocyte (Nash 1991) are referred to as subcuticular podocytes and they may provide a mechanism for the release of foreign material at the time of moulting.

The accumulations of immunopositive material that were found in the B-cell vacuoles of the hepatopancreatic epithelium was concentrated in the luminal side of the vacuoles and in some cases vacuoles appeared to discharge into the hepatopancreatic tubule lumen from which it passed to the gut. In addition to their digestive role (Gibson 1981, Al-Mohanna \& Nott 1986), B-cell vacuoles have been suggested to store waste products of digestion prior to their deposition into the tubule lumen for excretion (Gibson 1981, Al-Mohanna \& Nott 1986). This study would constitute the first report of B-cells also serving the function of excreting foreign material derived from the haemolymph. 
Some of the shrimp were observed to have positive material in the R-cell vacuoles $6 \mathrm{~h}$ after immersion. The R-cell's function is to absorb nutrients, store and metabolise lipid and carbohydrate. In this context the R-cells appeared to have absorbed bacterial components in a similar manner to any other source of nutrients. In this study whole bacteria did not appear to penetrate into the hepatopancreas. This supports the contention of Vogt (1997) that the normal decapod hepatopancreas is usually free of bacteria. Although intact bacteria have been reported in the hepatopancreas of farmed Penaeus monodon (Gomez-Gil et al. 1998).

In decapods, the stomach filtration process is carried out by the cardiac setal screen and the gland filter. The mesh size of the cardiac setal screen is extimated to be smaller than $1 \mu \mathrm{m}$ in several species of crabs (Powell 1974, Kunze \& Anderson 1979, Ngoc-Ho 1984). The gland filter occupies the ventral half of the pyloric chamber of the stomach and opens directly into the antechamber of the hepatopancreas. The ampullary setal screen mesh size can be as small as $0.05 \mu \mathrm{m}$ (Ngoc-Ho 1984), and the mesh size is also reduced by the overlap between the rows of setae. Kunze \& Anderson (1979) suggested that the gland filter acts as a means of final abrasion and reduction of particulate material, and not as a sieving mechanism. However, Hopkin \& Nott (1980) concluded for the crab Carcinus maenas that only particles with a diameter of $<0.1 \mu \mathrm{m}$ can pass through the filtering system of the setae at the opening of the primary ducts of the hepatopancreas. In their study, the coarse fraction containing all particles $>0.1 \mu \mathrm{m}$ in diameter was passed directly into the midgut. From this information and the size of bacterial cells of Vibrio spp. (0.5-1.5 by $1.5-4 \mu \mathrm{m}$; Austin \& Austin 1988), it would seem likely that intact sieves could prevent ingested bacteria from entering the hepatopancreas. It is possible that the gastric contents may also contribute to the lack of bacterial penetration into the hepatopancreas. Stewart et al. (1969) demonstrated that the $\mathrm{pH}$ of gastric contents of Homarus americannus had a bactericidal effect on the pathogen Gaffkya homari but less of an effect on other bacteria tested. In this study the interaction between gastric contents and bacteria was not examined but the hepatopancreatic extract did not influence bacterial survival.

This study clearly showed the gastric system is capable of excluding whole bacteria from the hepatopancreas, and it is possible that this could be an important defence mechanism for shrimp.

Bacterial exclusion does not appear to work in the opposite direction. Song et al. (1993) challenged Penaeus monodon with Vibrio damsela using anal intubation. The result was hepatopancreatic sepsis and shrimp death with as little as $10^{5} \mathrm{cfu} \mathrm{ml}^{-1}$. Bacteria might have gained access to the hepatopancreas because they were introduced with pressure against the anatomical arrangement of the filtration system. Hepatopancreatic sepsis was not achieved in any of our experiments and the conditions which determine the ability of potentially harmful bacteria to evade or escape this exclusion system are worthy of further investigation.

In conclusion, the defence response to the bacterial strain used in this study was extremely fast and efficient, resulting in rapid immobilisation and limitation in the spread of infection. A common system was observed for partial degradation of invading bacterial cells and excretion of undigested components. This involved a complex network of cells in haemolymph, gills, the connective tissue and hepatopancreas. The study indicated that oral invasion by whole bacteria is unlikely because of conditions in the stomach. In spite of these defences, the shrimp can obviously be overcome by bacteria under some circumstances.

\section{LITERATURE CITED}

Adams A (1998) Rapid diagnostic methods workshop manual. Aquatic Animal Health Research Institute, Bangkok

Alday-Sanz MV, Rodgers H, Turnbull T, Adams A, Richards R (1994) An immunohistochemical diagnostic test for rickettsial disease. J Fish Dis 17:189-191

Al-Mohanna SY, Nott JA (1986) B-cells and digestion in the hepatopancreas of Penaeus semisulcatus (Crustacea: Decapoda). J Mar Biol Assoc UK 66:403-414

Austin B, Austin DA (1988) Bacterial fish pathogens: disease in farmed and wild fish. Ellis Horwood, Chichester

Baumann P, Furniss AL, Lee JV (1984) Vibrio. In: Kreig NR (ed) Bergey's manual of systemic bacteriology, Vol 1. Williams \& Wilkins, Baltimore, p 518-538

Bell TA, Lightner DV (1988) A handbook of normal penaeid shrimp histology. World Aquaculture Society, Baton Rouge, Louisiana, USA

Brock JA, Lightner DV (1990) Diseases of Crustacea. Diseases caused by micro-organisms. In: Kinne O (ed) Disease of marine animals, Vol 3. John Wiley \& Sons, New York

Filip C, Fletcher G, Wulff JL, Earhart CF (1973) Solubilisation of cytoplasmic membrane of Escherichia coli by the ionic detergent sodium-lauryl sarcosinate. J Bacteriol 115: 3717-3722

Gibson P (1981) Feeding and ingestion in decapod crustaceans. In: Pruder GD, Langdon CJ, Conklin DE (eds) Proceedings of the second international conference on aquaculture nutrition: biochemical and physiological approaches to shellfish nutrition. Louisiana State University, Baton Rouge, p 59-70

Gomez-Gil B, Tron Mayen L, Roque A, Turnbull JF, Inglis V, Guerra-Flores AL (1998) Species of Vibrio isolated from the hepatopancreas, haemolymph and digestive tract of a population of healthy juvenile $P$. vannamei. Aquaculture 163:1-9

Hopkin SP, Nott JA (1980) Studies on the digestive cycle of the shore crab Carcinus maenas (L.) with special reference to the B cells in the hepatopancreas. J Mar Biol Assoc UK 60:891-907 
Kunze LC, Anderson DT (1979) Functional morphology of the mouthparts and gastric mill in the lermit crabs Clibanarius taeniatus, Clibanarius virescens, Paguristes squamosis and Daidanus setifer. Australian J Freshw Res 30:683-722

Lavilla-Pitogo CR, Baticados CL, Cruz-Lacierda ER, Leobert de la P (1990) Occurrence of luminous bacterial disease of Penaeus monodon larvae in the Philippines. Aquaculture 91:1-13

Mellon D (1992) Connective tissue and supporting structures. In: Harrison FW, Humes AG (eds) Microscopic anatomy of invertebrates. Decpod Crustacea, Vol 10. Wiley-Liss, Inc, New York, p 77-116

Nash GL (1991) Study of natural and induced tissue response in Macrobrachium rosenbergii de Man. PhD thesis, Institute of Aquaculture, University of Stirling, UK

Ngoc-Ho N (1984) The functional anatomy of the foregut of Porcellana platycheles and a comparison with Galathea squamifera and Upogebia deltaura. J Zool 203:511-535

Powell RR (1974) The functional morphology of the forguts of the Thalassinid crustaceans, Callianassa californiensis and Upogebia pugettenis. Univ Calif Publ Zool 102:41

Roque AM (1995) Development of a bath challenge for Vibrio spp. in Penaeus monodon Fabricius. PhD thesis, Institute of Aquaculture, University of Stirling, UK

Roque A, Turnbull JF, Escalante G, Gomez-Gil B, Alday-Sanz

Editorial responsibility: Timothy Flegel,

Bangkok, Thailand
MV (1998) Development of a bath challenge for the marine shrimp Penaeus vannamei Boone, 1931. Aquaculture 169:283-290

Smith VJ, Ratcliffe NA (1976) Defensive reactions of the shore crab, Carcinus maenas, to foreign particles. In: Angus TA, Faulkerner P, Rosenfield A (eds) Proceedings of the first international colloquium on invertebrate pathology. Kingston, Canada, p 312-313

Sparks AK (1981) Bacterial diseases of invertebrates other than insects. In: Devidson EW (ed) Pathogenesis of invertebrate microbial diseases. Allanheld, Osmum, Totowa, NJ, p 323-359

Soderhall K (1998) Review of crustacean immunity. The Fifth Asian Fisheries Forum, November 1998. Chang Mai, Thailand

Song YL, Cheng W, Wang CH (1993) Isolation and characterization of Vibrio damsela infections for cultured shrimp in Taiwan. J Invertebr Pathol 61:24-31

Stewart JE, Dockrill A, Cornick JW (1969) Effectiveness of the integument and gastric fluid as barriers against transmission of Gaffkya homari to the lobster Homarus americanus. J Fish Res Board Canada 26:1-14

Vogt G (1997) Hepatopancreatic brush border lysis (HBL)—a new bacterial disease of the shrimp Palaemon elegans. Dis Aquat Org 29:151-155

Submitted: December 14, 1998; Accepted: August 13, 2001

Proofs received from author(s): February 18, 2002 